\title{
On Arabo-Persian Elements in modern Bengali
}

\section{Tomio Mizokami}

Bengali is well known as a Sanskrit-oriented language, but the existence of Arabic and Persian elements is quite obvious. This is quite natural, as Bengal was under the Muslim rule over five hundred years, and the majority of the local population converted to Islam.

As S. K. Chatterji points out ${ }^{1)}$, Arabo-Persian influence on Bengali has been mainly lexical; whereas Persian has influenced Hindi not only lexically but also idiomatically or sometimes even grammatically. This difference between Hindi and Bengali is due to the geographical conditions. Hindi was the language of Madhya Desha (Central country) where the center of a Muslim rule was established, but Bengal was far from the center of a Muslim rule.

According to S. K. Chatterji's count on the basis of Jñādendra Mohan Dās's Bañglā Bhāṣār Abhidhān (Calcutta, 1916) which contains some 75, 000 words and compounds, the total number of Arabo-Persian words is about 2,500 $(3.30 \%)^{2)}$. My own count on the basis of Bangiya Shabda Koșa) (New Delhi, 1966-1967) shows that Arabic words are about 700 and Persian words are about 650 , hence the percentage of Arabo-Persian words in this dictionary is slightly less than $3 \%$. Perhaps this can be taken as an indication of a change. Though the number of Arabic words is slightly more than that of Persian words, the frequency of Persian words appears to be more. This is due to the fact that whereas Arabic has more technical terms, which are

1) The Origin and the Development of the Bengali Language (O. D. B. L.), Calcutta, 1926, pp. 201-202.

2) O. D. B. L., p. 218 .

3) This dictionary is of a high standard, though the entries are less than Bangla Bhāsăr Abhidhān. But Arabic dokan 'shop' is mistakenly explained as Persian. (p. 1135) 
limited to religion, politics and administration etc., Persian vocabulary is used for things of daily life. Arabic words (Turkish words, too) are very rarely borrowed into Bengali directly, most of them have come to Bengali through Persian. Therefore Arabic sounds have been already Persianized.

Below are the examples to show how Arabo-Persian words appear in Bengali : - (A. means Arabic, and P. means Persian.)

“Babu, tomar jemon ekți larki ace, temni deše amar o ekți larki ace. ami tahar i mukhkhani šson koriya tomar khõkhir jonno kichu kichu mewa hate loiya aši, ami to šouda korite aši na".

ei boliya še apnar mosto dhila jamațar bhitor hat calaiya diya buker kache kotha hoite ek tukra moyla kagoj bahir korilo. bohu jotne bhãj khuliya dui hoste amar tebiler upor meliya dhorilo.

dekhilam, kagojer upor ekți choțo hater chap. photograph nohe, teler chobi nohe, hate khanikța bhuša makhaiya kagojer upor tahar $i$ cinno dhoriya loiyace. meyer ei šsoron cinnoțuku buker kache loiya rohmst proti botšsor kolikatar $\frac{\text { rastay }}{\mathrm{P} \text {. }} \frac{\text { mewa becite aše. (Rabindranath Tagore, kabuliwala) }}{\mathrm{P} \text {. }}$

("Babu, you have a little girl; I too have one like her in my home.

I think of her, and bring some fruits for your child- they are not for sale". Saying this, he put his hand inside his big loose robe and brought out a small and dirty piece of paper from near his breast. Unfolding it with great care, he placed it with both hands on my table.

It bore the impression of a little hand. Not a photograph, not a drawing, merely the impression of an ink-besmeared hand laid flat on the paper. Keeping this memento of his own little daughter next to his heart, Rahamat had come year after to Calcutta to sell his fruits in the streets.- Translation as quoted in Bidhubhusan Dasgupta's Learn Bengali Yourself. ((Calcutta, 1966))

jadsb mukhuje o madhsb mukhuje je šshodor chilen na, še kstha nijera to bhuliyai chilen, bahirer lok $\frac{o}{\mathrm{P} .}$ bhuliyaichilo. doridro jadsb onek ksšte choțo bhai madhobke ain paš koraiyachilen ebom bohu cešțay dhonadho 
On Arabo-Persian Elements in modern Bengali (T. Mizokami)

jomidarer ækmatro šontan bindubašinike bhratribodhurupe ghore anite šskhom hoiyachilen. bindubašini sšamanno rupoši. prothom jedin še ei otul rup $\frac{o}{\mathrm{P} .}$ doš šshosro țakar $\frac{k a g \jmath j}{\mathrm{P} .}$ loiya ghor korite ašiyachilo, šedin borobou onnopurnar chokhe ansndasru bohiyachilo. barite šašuri nonsd chilo na, tini $i$ chilen grihini. choțobodhur mukhkhani tuliya dhoriya protibašinider kache šjgorbe boliyachilen, "ghore bou ante hoy to emni! ekebare lokkhir protima". kintu dui dinei tãhar e bhul bhãgilo. duidinei țer pailen, choṭobou je ojone rup $\frac{o}{\mathrm{P} .}$ taka aniyache, tahar cotur gun shõkar obhiman $\frac{o}{\mathrm{P} .}$ s̃oge aniyache. ækdin borobou šamike nibhrite dakiya kohilen, "hã ga, rup ar takar pütli dekhe bou ghore anle kintu e je keuṭe šap!" jadıb ksthața biššas korilen na. matha culkaiya bar dui tai to tai to koriya kachari coliya gelen. jadsb

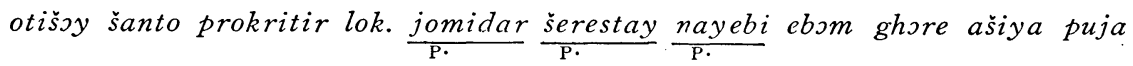

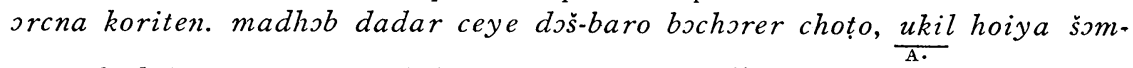
proti bæbš̌a šuru koriyachilo. še ašiya kohilo, "bouțhan, țakațai ki dadar

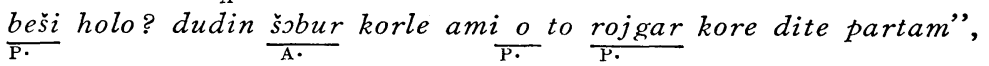

(Sarat Chandra Chatterji, Bindur Chele)

(Yadav Mukherji and Madhav Mukherji were not uterine brothers-this had been forgotten not only by themselves, but also by other people. With much trouble, poor Yadav had made his younger brother Madhav pass the law examination, and after much efforts succeeded in bringing Bindubasini, a rich landlord's only daughter to his house as his sister-in-law. Bindubasini was extraordinarily beautiful. At the first day when she came to live with her husband with a promissory note of ten thousand rupees, Annapurna, Yadav's wife, was in tears of joy. As there was no mother-in-law or sisterin-law at home, she was the only housewife. Raising Bindu's face, she said proudly to the ladies of neibourhood, "Can there be such a wonderful bride to bring home? She is just like the idol of Goddess Laxmi !" But within two days it was disclosed that she had been mistaken. She came to know within two days that Bindu's pride and conceit were four times more than her beauty and money brought by her. One day Annapurna called her husband secretly and said, "My dear, you brought the bride to our house seeing 
beauty. and a packet of money, but she is a cobra!" Yadav did not believe her story. He, scrathcing his head, saying "Is that so? Is that so?" twice or thrice, went to office. Yadav was a very peaceful-minded person. He was just working as a deputy at a landlord's office, and then passing his time worshiping and praying God at home. Madhav was ten or twelve years younger than his brother, and he had recently begun his profession as a lawyer. He came and said, "Say, did my brother require much money? If he had endured two days more, I also could have given him money by doing the business".)

(Translation is mine.)

The frequency of Arabo-Persian words in Bengali is, of course, not fixed but flexible depending on the type of literature and writer who uses it. The most typical Persianised novel (romance) in Bengali is said to be the "Barāa Dāstān Amīr Hāmzã", and this includes 31.74\% Arabo-Persian words"s). It is unavoidable to lean on Arabo-Persian in historical or religious subjects based on Islamic culture and tradition. But it is noteworthy that even this type of story includes much fewer Arabo-Persian words than Urdu. In the works of Rabindranath Tagore, the most eminent Bengali writer, more AraboPersian words are found than those of Bankim Chandra Chatterji, but less than those of Sarat Chandra Chatterji5).

Roughly speaking, the percentage of Arabo-Persian words in modern Bengali would not be higher than $10 \%$. In the daily conversation of Bengali among the upper or middle classes of Hindu, the percentage of Arabo-Per sian words is said to be $7.1 \%$, and the Hindu women of the upper classes use lesser than that ${ }^{6}$ ). This is a very interesting phenominon. The reason would probably be that women have fewer chances to associate with the people of outer circle. Muslims are likely to use somewhat more Arabo-Persian words than Hindus, but they are confined to the terms concerning religion, relations (eg. bhai saheb 'elder brother' instead of dada), the expressions of
4) O. D. B. L., p. 211.
5) I have limited the study to Bengali fiction only.
6) O. D. B. L., p. 211 . 
On Arabo-Persian Elements in modern Bengali (T. Mizokami)

greetings or gratitude (eg. šalam walaikum 'good morning' 'good afternoon' etc. instead of nomsškar, sukriya 'thank you' instead of dhonnobad.), and some adverbial experssions (eg. thora 'a little' instead of ektu). The last one would be rather the influence of Urdu.

I am not of the opinion that "Musalmani Bengali" is a seperate style or dialect from ordinry Bengali. The difference of style in Bengali is not according to religion. It lies between colloquial style (Calit Bhassa) and literary style (Sädhu Bhāṣa). Today the $S a \bar{a} h u$ Bhạsa is rarely used except in the cases of writing novels, and a formal document, or delivering a formal speech. Sãdhu Bhãșa is based on Middle Bengali of about 500 years ago, hence it prefers a stiff style of the Sanskrit type. Naturally more AraboPersian words are used in Calit Bhạsă than in Sädhu Bhãsă. The Sãdhu

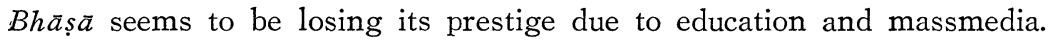

As regards the semantic changes of Arabo-Persian words in Bengali, examples may be given as follows:-

ašsl means 'origin' in Arabic, but means 'real' in Bengali.

Similarly

chobi 'picture' < 'resemblance' in Arabic

demak 'pride' or 'vanity' < 'brain' in Arabic

gorib 'poor' < 'foreign' in Arabic

photur 'poor' > 'defect' in Arabic

talak 'oath' < 'divorce' in Arabic

nikah 'widow marriage of a Muslim' < 'marriage' in Arabic

šada 'white' < 'simple' in Persian

bešs 'good' < 'more' in Persian

phošsl 'harvest' or 'crops' < 'season' in Arabic

gum 'corpes' < 'lost' in Persian 